Article

\title{
Understanding the Hydropower and Potential Climate Change Impact on the Himalayan River Regimes-A Study of Local Perceptions and Responses from Himachal Pradesh, India
}

\author{
Netrananda Sahu ${ }^{1,2, *(\mathbb{D}}$, Takahiro Sayama ${ }^{2} \mathbb{(}$, Atul Saini ${ }^{1}{ }^{1}$, Arpita Panda ${ }^{1}$ and Kaoru Takara ${ }^{3}$ \\ 1 Department of Geography, Delhi School of Economics, University of Delhi, New Delhi 110007, India; \\ atulsainimail@gmail.com (A.S.); arpitapanda1991@gmail.com (A.P.) \\ 2 Disaster Prevention Research Institute, Kyoto University, Gokasho, Kyoto 6110011, Japan; \\ sayama.takahiro.3u@kyoto-u.ac.jp \\ 3 Graduate School of Advanced Integrated Studies (GSAIS) in Human Survivability (Shishu-Kan), \\ Kyoto University, Kyoto 606-8501, Japan; takara.kaoru.7v@kyoto-u.ac.jp \\ * Correspondence: babunsahu@gmail.com
}

Received: 2 September 2020; Accepted: 25 September 2020; Published: 30 September 2020

\begin{abstract}
The Himalayas have become synonymous with the hydropower developments for larger electricity demands of India's energy sector. In the Himachal Himalayas though, there are only three large storage dams with more than 1000 megawatts (hereafter MW) capacity that have very serious environmental issues. However, hundreds of small runoff-river hydropower plants across the Himachal Himalayas are a serious threat to the river regimes and Himalayan biota. There are 965 identified hydropower projects (hereafter HPPs) having a potential capacity of 27,436 MW in the Himachal Pradesh as of December 2019 as per the Directorate of Energy of the state. Out of the 965 identified, 216 are commissioned, including less than 5 MW plants, with an installed capacity of 10,596 MW, and were operational by December 2019. Only 58 projects are under construction among the identified with an installed capacity of $2351 \mathrm{MW}, 640$ projects are in various stages of clearance and investigation with an installed capacity $9260 \mathrm{MW}, 30$ projects are to be allotted with $1304 \mathrm{MW}$ installed capacity, and merely four projects are disputed/cancelled with installed capacity of $50.50 \mathrm{MW}$. The large number of HPPs are sanctioned without proper consideration of negative environmental and geohazard impacts on the Himalayan terrestrial biota. In this work, our focus was on the hydropower and climate change impact on the Himalayan river regimes of the Chenab, the Ravi, the Beas, the Satluj, and the Yamuna river basins. We analyzed basin-wise rainfall, temperature, and soil moisture data from 1955 to 2019 to see the trend by applying the Mann-Kendall test, the linear regression model, and Sen's slope test. A basin-wise hazard zonation map has been drawn to assess the disaster vulnerability, and 12 hydropower sites have been covered through the primary survey for first-hand information of local perceptions and responses owing to hydropower plants.
\end{abstract}

Keywords: hydropower plants; climate change; Himalayas; runoff-river; disasters

\section{Introduction}

The Himalayas have become synonymous with the hydropower developments for larger electricity demands of India's energy sector. India's hydropower requirement has been largely contributed by the western and eastern Himalayan river systems [1,2]. The Himalayan rivers are vulnerable to climate change, and dams are a big threat to the Himalayan biodiversity [3]. Hydropower is one of the major renewable sources of energy of the world, and there is a boom in the hydropower sectors across the 
globe $[4,5]$. There are unprecedented increases in dams' constructions in the most ecologically sensitive and diverse biota of the Amazon, Congo, Mekong [6,7], and Indus [8]. Extraction of hydropower from the riverine ecosystems through run-of-river hydropower, storage hydropower, and pumped-storage hydropower systems are well-known electricity generation systems. Hardly any big rivers are left in the world where there is no dam for the hydropower purpose and dam-making by humans, which is more than 5000 years old, is one of the major anthropogenic activities that meted out to fulfill the greater electricity demands [9]. As per the International Hydropower Association status report of 2019, total hydropower installed capacity was 1292 gigawatts by 2018 from 289 countries, in which $80 \%$ are from the top 20 countries. Of note, 21.8 gigawatts are the new installed capacity in 2018 only with East Asia, and the Pacific is leading the table that is followed by South America, South and Central Asia, Europe, Africa, and North and Central America [10]. India is one of the major hydropower-producing countries in East Asia, with China being the largest producer. Within India, hydropower productions vary from region to region. Among the northern states of India, Himachal Pradesh has the second largest potential capacity of hydropower generation after Arunachal Pradesh. The hydropowers in the Himachal Pradesh depend on the Chenab, the Ravi, the Beas, the Satluj, and the Yamuna river basins and their sub-basins.

In this research work, we focused on hydropower and its impact on the Himalayan river regimes, taking the second-largest potential hydropower capacity of Himachal Pradesh as a case study. There are 965 hydropower projects (HPPs) (Figure 1) with 27,436 MW installed capacity in the Himachal Pradesh and 10,596 MW of energy were already in production by December 2019 (Table 1). Here, we analyzed the long-term trend from 1955 to 2019 for 65 years of the mean annual, monsoon season of June, July, August, and September (hereafter JJAS) and the winter season of December, January, and February (hereafter DJF) rainfall, soil moisture, and temperature across all the five river basins to assess the hydropower impact within Himalayan river regimes and biodiversity with unavailability of reservoirs and streamflow data. Particularly basin-wise pattern of rainfall, soil moisture, and temperature scenarios and how the numerous hydropower projects affect the local people were assessed. We conducted two rounds of pilot field surveys in February and October of 2019 and covered 12 hydropower sites in total, four from each basin (the Ravi, the Beas, and the Satluj) across three districts of Chamba, Kullu, and Kinnaur of Himachal Pradesh to assess the impact of hydropower on the Himalayan river regimes and biodiversity from local perceptions and responses.

Table 1. Status of hydropower project (HPP) potential in various river basins and its sub-basins as of December 2019 (Source: Directorate of Energy, Govt. of Himachal Pradesh).

\begin{tabular}{ccc}
\hline Status of HPP & No. of Plants & $\begin{array}{c}\text { Installed Capacity MW } \\
\text { (Megawatt) }\end{array}$ \\
\hline Commissioned & 216 & $10,596.27$ \\
\hline $\begin{array}{c}\text { Under construction/Various Stages of } \\
\text { Clearance \& Investigation }\end{array}$ & 709 & $11,612.24$ \\
\hline To be allotted & 30 & 1304.5 \\
\hline Disputed/Cancelled & 4 & 50.5 \\
\hline Foregone & 6 & 755.00 \\
\hline Total allotted & 965 & $27,436.00$ \\
\hline
\end{tabular}




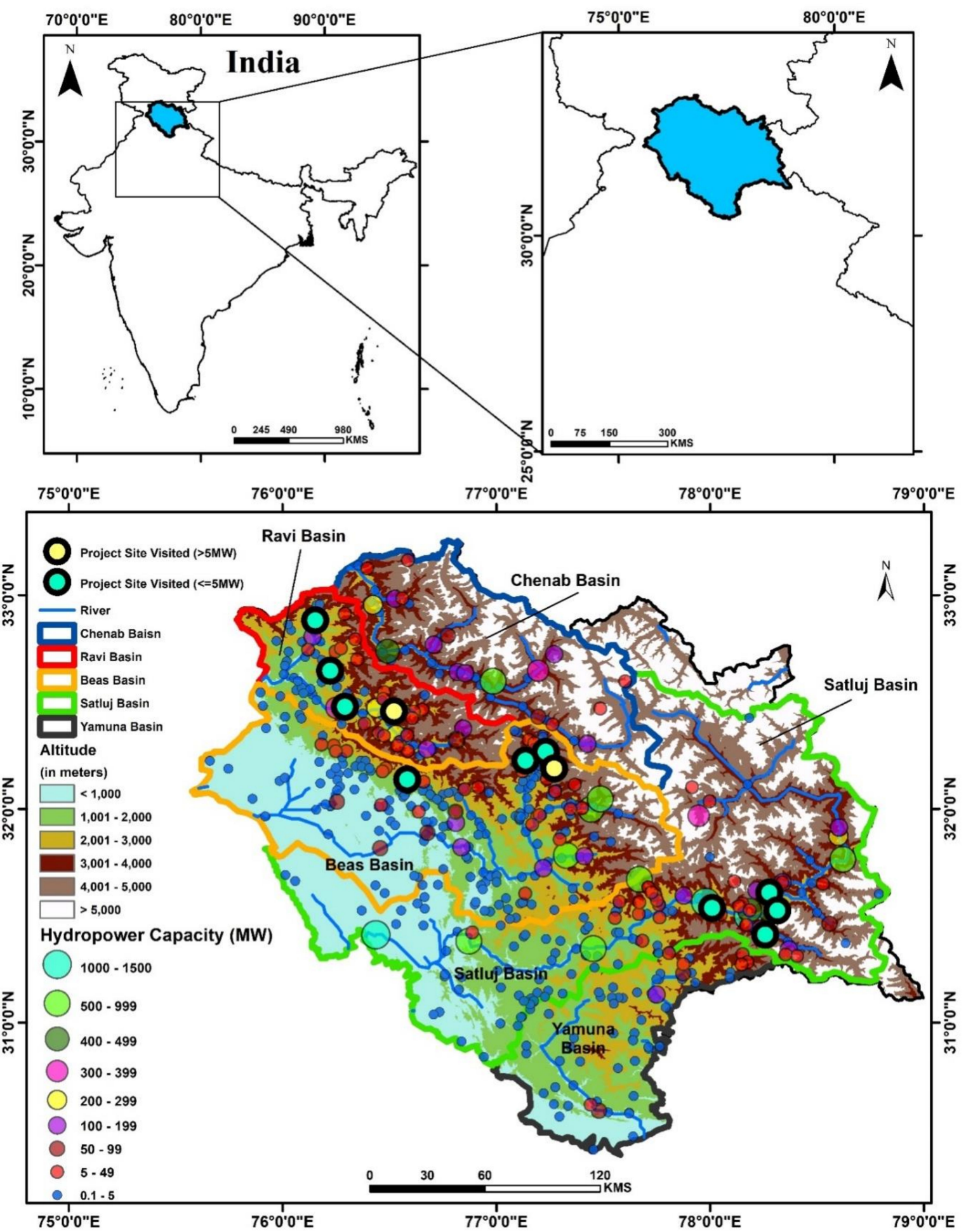

Figure 1. Basin-wise distribution of hydropower projects of all those commissioned and under construction in the Himachal Pradesh.

\section{Data and Methods}

Rainfall and surface temperature grid data were obtained from the India Meteorological Department. The spatial resolution of the rainfall data is $0.25^{\circ} \times 0.25^{\circ}$ [11], and for temperature, it is $1^{\circ}$ $\times 1^{\circ}$ [12]. The unit of rainfall in this study is millimeter $(\mathrm{mm})$. National Centers for Environmental Prediction (NCEP) and the National Center for Atmospheric Research (NCAR) soil moisture reanalyzed 
data [13] for 10-200 cm depth were obtained from the Lamont-Doherty Earth Observatory (IRI/LDEO) Climate Data Library of Columbia University, New York. The spatial resolution of the soil moisture reanalyzed data is $1.875^{\circ} \times 1.875^{\circ}$. Climate variables of rainfall, temperature, and soil moisture spatial distribution analyses were done for five years' mean basis (pentad basis) to understand the change in the spatiality of the variability within the Chenab, the Ravi, the Beas, the Satluj, and the Yamuna river basins. With the unavailability of streamflow and reservoirs data, we calculated the trend analysis of annual, JJAS, and DJF seasons' rainfall, soil moisture, and temperature using a linear regression (parametric) model (hereafter LRM), Mann-Kendall test (non-parametric) (hereafter MKT) [14], and Sen's slope [15] to investigate the basin-wise pattern. Calculation of the trend was done using the spatialized area averaged data of each river basin. Area average of the basin was obtained using the "fldmean" function in Climate Data Operators (http://mpimet.mpg.de/cdo).

Mann-Kendall Test: The M-K test is a non-parametric test in statistics mainly used for trend analysis in hydrological and climatological time series data. This test was given by Mann (1945) and has been used extensively with environmental time series. Mainly, this test has two advantages: firstly, as it is a non-parametric test, hence the data used need not be normally distributed; secondly, the test has low sensitivity to abrupt breaks due to inhomogeneous time series. According to this test, the null hypothesis, i.e., $\mathrm{H}_{0}$, assumes that there is no trend in the data series, meaning that the data are independent and randomly distributed, whereas the alternative hypothesis, i.e., $\mathrm{H}_{1}$, assumes that there is a trend. The M-K statistic is computed as follows:

$$
S=\sum_{i=1}^{N-1} \sum_{j=i+1}^{n} \operatorname{sgn}(x j-x i)
$$

where $X j$ and $X i$ are the annual values in years $j$ and $i$, respectively, and $N$ is the number of data points. The value of sign $(X j-X i)$ is computed as follows:

$$
\operatorname{sgn}(x j-x i)=\left\{\begin{array}{c}
1 \text { if }(x j-x i)>0 \\
0 \text { if }(x j-x i)=0 \\
-1 \text { if }(x j-x i)<0
\end{array}\right.
$$

Linear Regression Model: These models are used to show or predict the relationship between two variables or factors. In statistics, this is a linear approach of modelling the relationship between a scalar response (dependent variable) and explanatory variables. It is computed as:

$$
\mathrm{Y}=\mathrm{a}+\mathrm{b} \cdot \mathrm{X}
$$

where $\mathrm{Y}=$ dependent variable, $\mathrm{X}=$ independent variable, $\mathrm{b}=$ slope.

In both the $\mathrm{M}-\mathrm{K}$ test and Linear Regression model, Z-stat value explains whether there is a positive or negative trend in the data series, and the slope value denotes the magnitude of trend.

In the $\mathrm{M}-\mathrm{K}$ test, $\mathrm{Z}$-stat value provides a trend statistic $(\mathrm{Z})$ that indicates the monotonic increasing (positive $z$ ) or decreasing (negative $Z$ ) trend. If the value of the $Z$-statistic is non-significant at a given alpha level $(0.05,0.01)$, we can infer that there is no trend in the time series, and Sen's slope is basically used to identify the magnitude of the trend in a data series.

\section{Primary Survey}

The impact of hydropower on Himachal Pradesh has been studied, based on perception observation of local peoples in the Chamba, Kullu, and Kinnaur districts of the Ravi, the Beas, and Satluj basins, respectively. We visited 12 different hydropower sites for verification of change on the ground, perceptions, and observations of local peoples and problems they faced due to hydropower plants. Two rounds of purposive sampling surveys were conducted at 12 sites (highlighted in Figure 1), 4 sites from each river basin, and a total of 120 people interacted, 10 from each site with questionnaires and 
confirmed participants' observations and opinions. The intensive field investigations were conducted in February and October 2019.

\section{Hydropower and Climate Change}

The hydropower, renewable energy is a popular resource worldwide, many times considered as problems for environmental, ecological, and social aspects, during construction to operational phases [16-18]. Environmental degradation is a very serious issue, and it varies from country to country with site-specific geographical, geological, and topographical impacts. The environmental issues vary from large, medium, to small dams [19]. In the Himachal Himalayas though, there are three very large storage dams, i.e., Bhakra Nangal, Naphtha Jhakri, and Karcham, but all are on the Satluj river with more than 1000 MW capacity, which has very serious environmental issues; however, hundreds of small runoff-river hydropower plants across all the basins in the Himachal Himalayas are a serious threat to the river regimes (Figure 2). The hydropower plants that use the runoff-river tunnel to divert natural water flow in the streams have serious ecological problems in the climate change scenarios in the Himachal Himalayas. The increasing trend of global mean temperature [20] leads to unequivocal disruptions in the patterns of precipitation, snow melting, water availability, and hydrological cycles [21] in many parts of the earth, including the Himalayan states of India [22]. Runoff is influenced by the pattern of precipitation in a basin induced by climate variability, climate change, and local factors [23-25]. In the case of the Himachal Himalayas that consist of the Shiwaliks (outer Himalayas), the lesser Himalayas and the Greater Himalayas have regional-to-local variations of total precipitation patterns [26-28]. The climate in the Himachal Pradesh varies with elevations from below $300 \mathrm{~m}$ in Una and Hamirpur to more than $7000 \mathrm{~m}$ in Kinnaur and Lahul and Spiti. Several studies have been done in the Himachal Himalayas regarding the contribution of snow to the total precipitation to the runoff in rivers. It has been estimated that, in the Chenab basin, there are $49 \%$ contributions from the snow and glaciers melting [29], in the Satluj basin, the contribution is $60 \%$ [30], and, in the case of the Beas, it has been estimated to be $35 \%$ of the water from the snow and glaciers melting [31]. At $2000 \mathrm{~m}$ elevation, rain and snow contribute equally in the Himachal Pradesh [32]. Jaiswal et al. [33] suggested that, in the Himachal Pradesh, there is a decrease in annual, winter, monsoon, and post-monsoon rainfall from 1951 to 2005 datasets based on 37 measuring stations. In the last 100 years, there has been a decrease in monsoon rainfall by $61 \mathrm{~mm}$ in Himachal Pradesh [34], and rainfall is in a decreasing trend across all the districts [35]. The number of rainy days is decreasing at Palampur, famous for tea plantation [36]. At Shimla, the capital of Himachal Pradesh known for apple cultivations, a famous tourist spot and hill station, total precipitation and snowfall is decreasing, as suggested by previous studies $[35,37]$. Hence, the impact of climate change is evident within Himachal Pradesh. To investigate further, we analyzed all the five basins' rainfall, temperature, and soil moisture from 1955 to 2019 for 65 years in this work. 

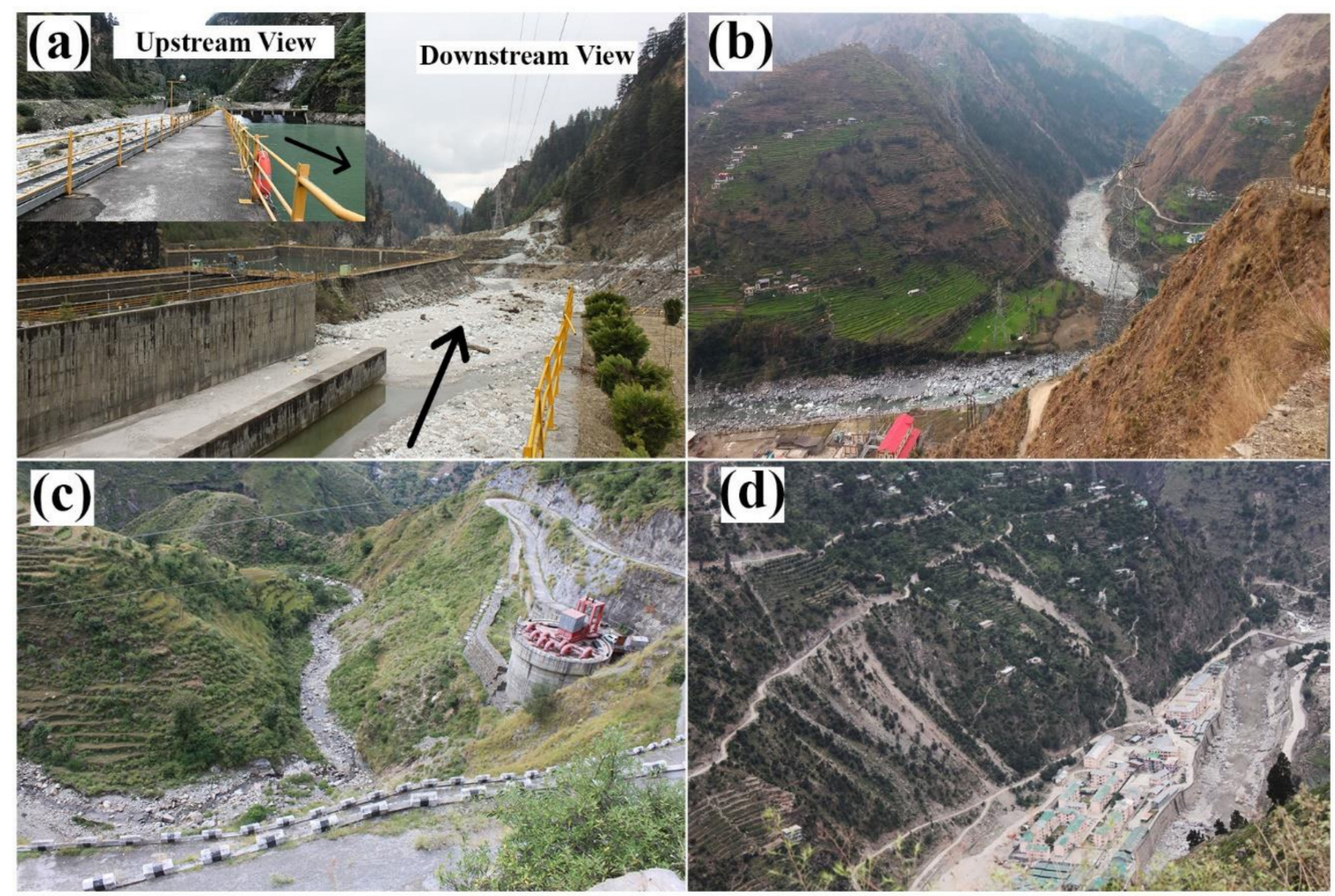

Figure 2. Dry river channel after stream water diverted/blocked for hydropower purposes at (a) Parbati sub-basin of Beas basin of Kullu districts (b,c) Ravi basin of Chamba districts, (d) Satluj basin of Kinnaur districts. All the photographs were taken during our primary survey.

\section{Results}

\subsection{Basin-Wise Rainfall, Temperature, and Soil Moisture Trend}

\subsubsection{Basin-Wise Spatial Distributions}

Basin-wise spatial distributions of total annual rainfall pentads show decreasing rainfall within the Satluj basin after 1955-1959 till 2015-2019, and the 1970-1974 and 2000-2004 periods are very seriously affected in almost all the basins (Figure 3). DJF (Figure S1, S hereafter Supplementary Material) winter and JJAS (Figure S2) monsoon seasons pentads show similar spatial patterns across all the basins. Overall spatial rainfall distributions across all the five river basins indicate that there is declining of rainfall annually as well as seasonally; how this will influence the hydropower plants in the future will need to be observed seriously. Analysis of temperature in all the five river basins, for JJAS, DJF, and the annual trend, has been carried out to assess the basin-wise impact across Himachal Pradesh. The annual five-years mean pentad figures from 1955 to 2019 show (Figure 4) that the temperature decreases from south to north as lower catchments are having low elevations with high-temperature distributions compared to upper catchments and elevations increases from south to north for all the basins, hence decreasing of temperature from south to north is homogenous in the whole region. Similar observations of temperature distribution have been found during the DJF winter seasons.

The mean pentad figures for DJF (Figure S3) across all the basins show similar distributions, but from the 1955 to 1959 to 2015 to 2019 pentads, we can see that winters are not so cold, and the gradual mean surface temperature shifting towards upper catchments is very clear in the spatial distributions pattern in the pentads that affect the snow cover depth, which may influence the hydropower plants; however, temperature shifting towards upper catchment is not very prominent during the JJAS season (Figure S4). However, the increase in overall temperature in the whole Himachal Pradesh of almost 
$0.5^{\circ} \mathrm{C}$, as observed by Sahu et al. [35], may lead to more water in reservoirs of the Chenab and the Satluj basins.
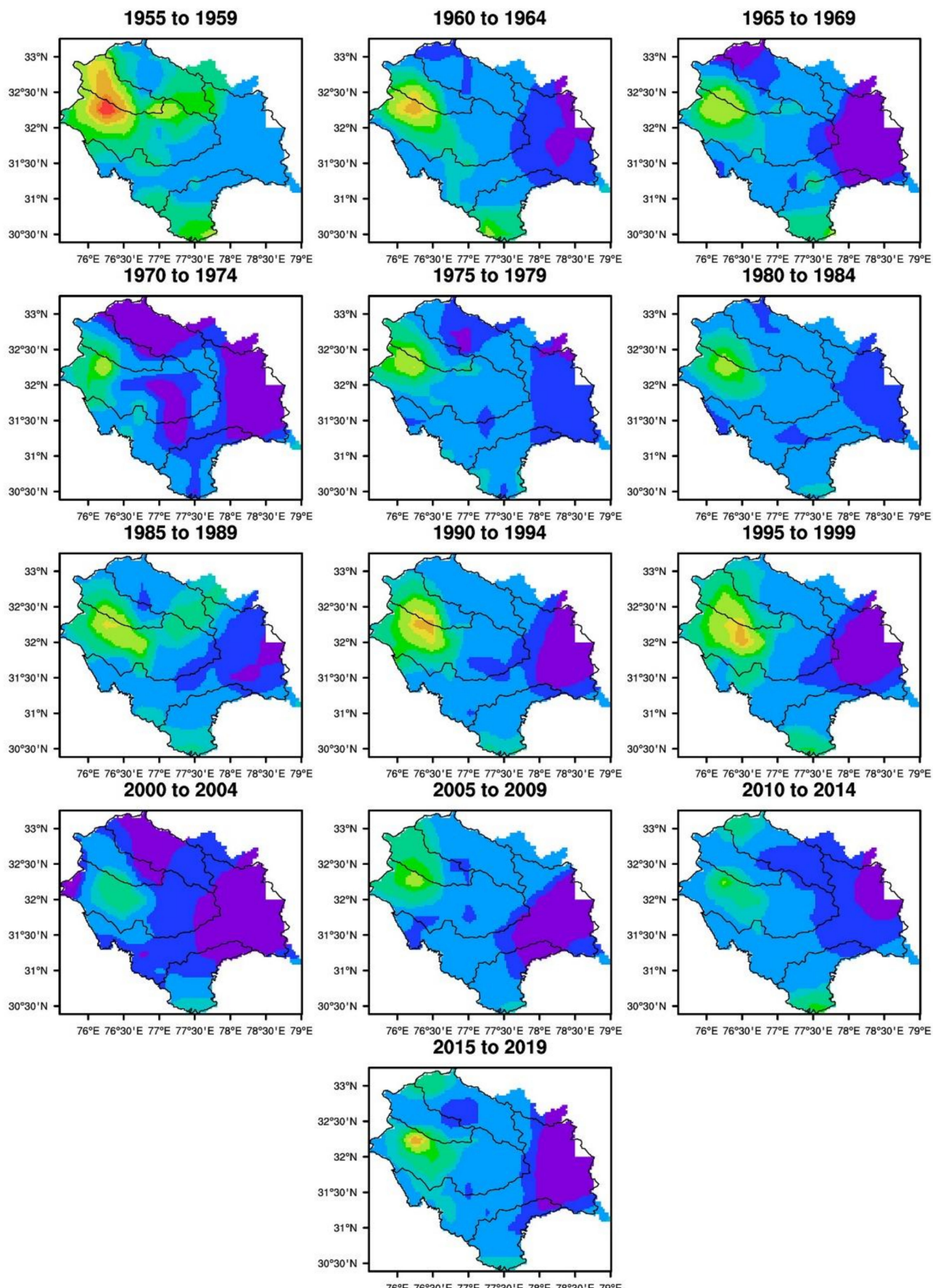

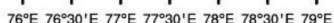

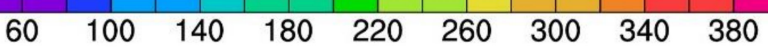

Figure 3. Pentads showing total annual rainfall in five river basins of the Himachal Pradesh. Each pentad shows the mean of the five years from 1955 to 2019. 


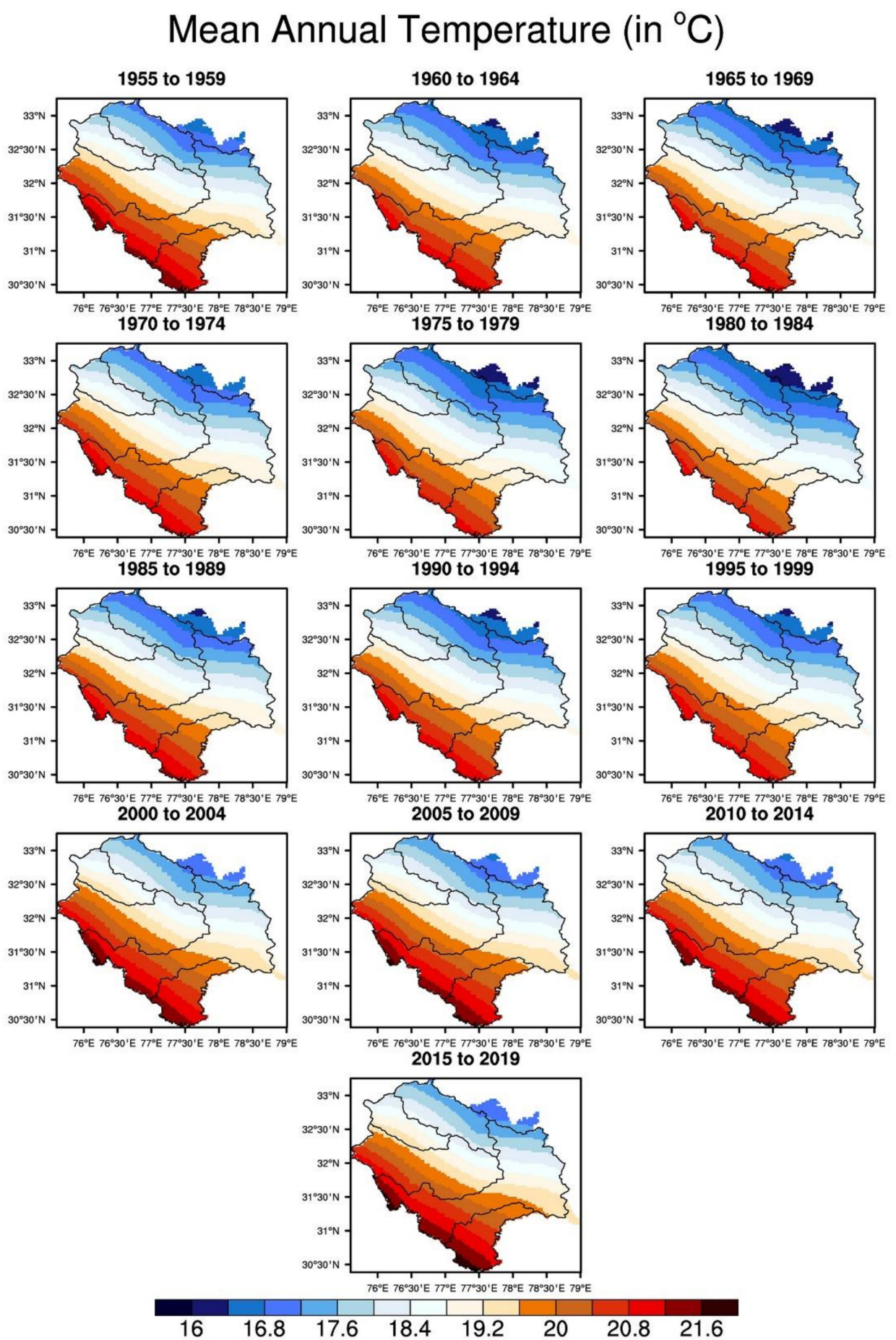

Figure 4. Pentads showing mean annual temperature in five river basins of the Himachal Pradesh. Each pentad shows the mean of the five years from 1955 to 2019.

Annual soil moisture pentads of all the basins show a very clear spatial pattern of a gradual increasing shift towards upper catchment (Figure 5). DJF winter (Figure S5) and JJAS summer (Figure S6) seasons pentads show similar spatial distributions of soil moistures across all the basins with higher area coverage of soil moistures within the upper catchments, which may be owing to snow and glaciers melting along with torrential monsoon rainfall. 

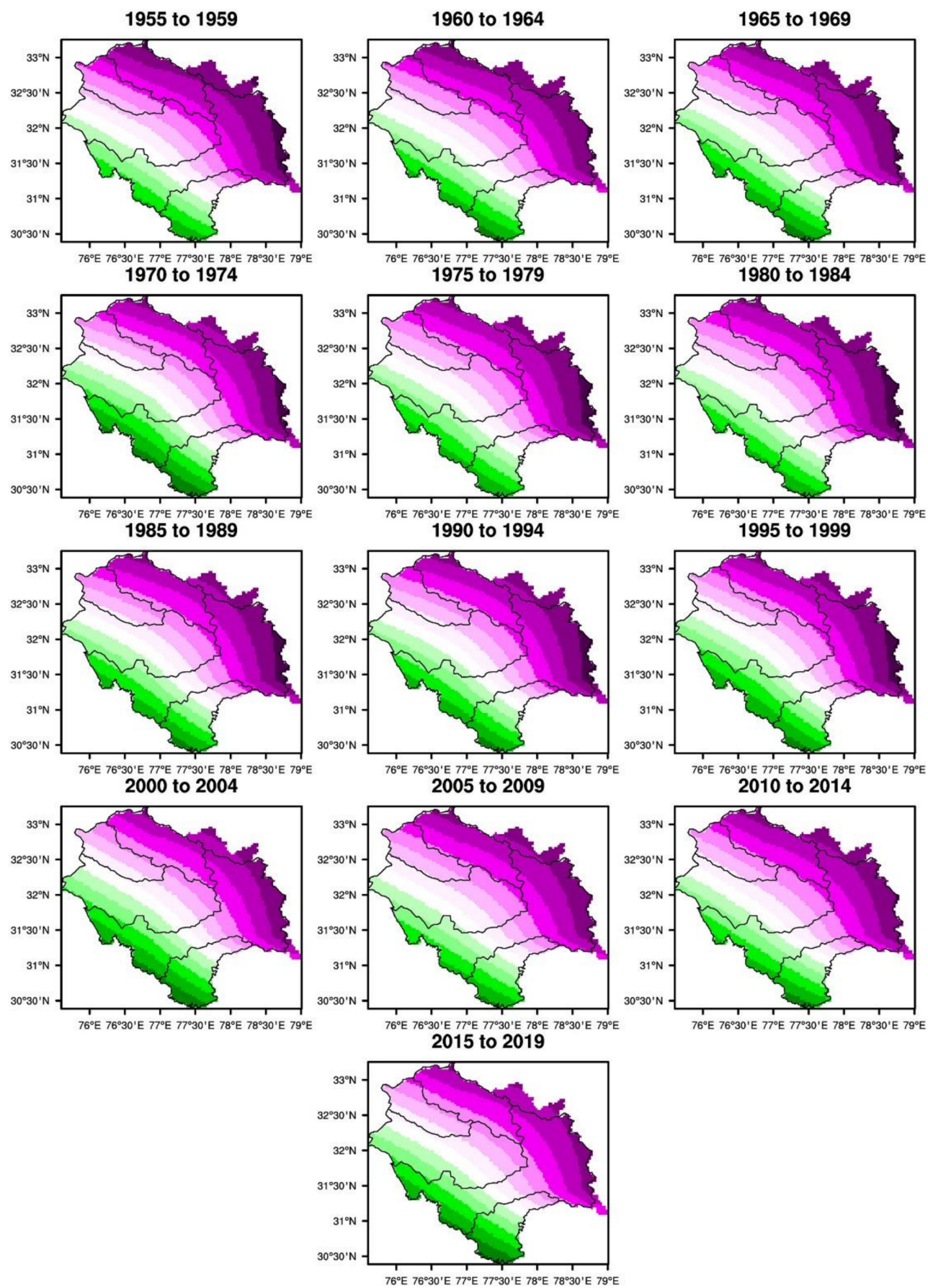

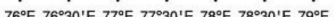

889296100104108112116120124128132136

Figure 5. Pentads showing total annual soil moisture in five river basins of the Himachal Pradesh. Each pentad shows the mean of the five years from 1955 to 2019.

\subsubsection{Basin-Wise Trend}

An increasing trend of the mean annual, JJAS, and DJF temperatures has been found for 65 years analysis from 1955 to 2019 across all the five river basins. The annual mean temperature and total rainfall are inversely associated for all the river basins during the period, that is, with increasing annual mean temperature, annual total rainfall is decreasing (Figure 6a-e). For the JJAS summer (Figure $6 \mathrm{f}-\mathrm{j}$ ) season, the temperature is in an increasing trend for all the river basins and rainfall is in a decreasing trend in the Ravi, the Beas, and the Yamuna, and an increasing trend in the Chenab and the Satluj due 
to the melting of snow and glaciers within the catchments. For the DJF winter season, temperature and rainfall have a similar pattern as the mean annual trend within all the basins (Figure 6k-o).

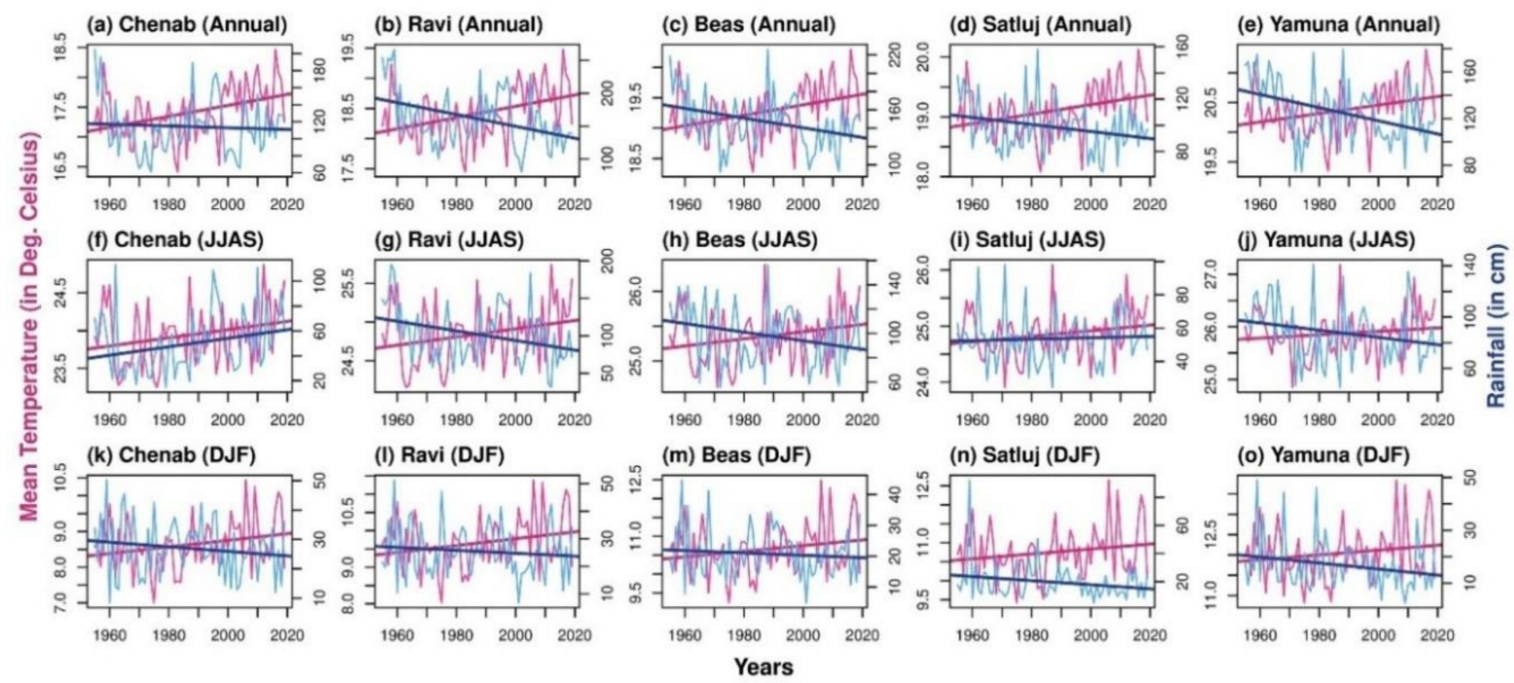

Figure 6. Basin-wise trend of mean temperature and total rainfall for annual, JJAS, and DJF seasons for the 1955-2019 period.

Mean annual (Figure 7a-e), JJAS (Figure 7f-j), and DJF (Figure 7k-o) seasons' soil moisture and temperature trend show an inverse association with each other. Soil moisture is homogeneously decreasing (Table 2) across all the basins in all seasons like rainfall. With the diversion of stream water for HPP through concrete tunnels, the Himalayan biota is going to be seriously affected.

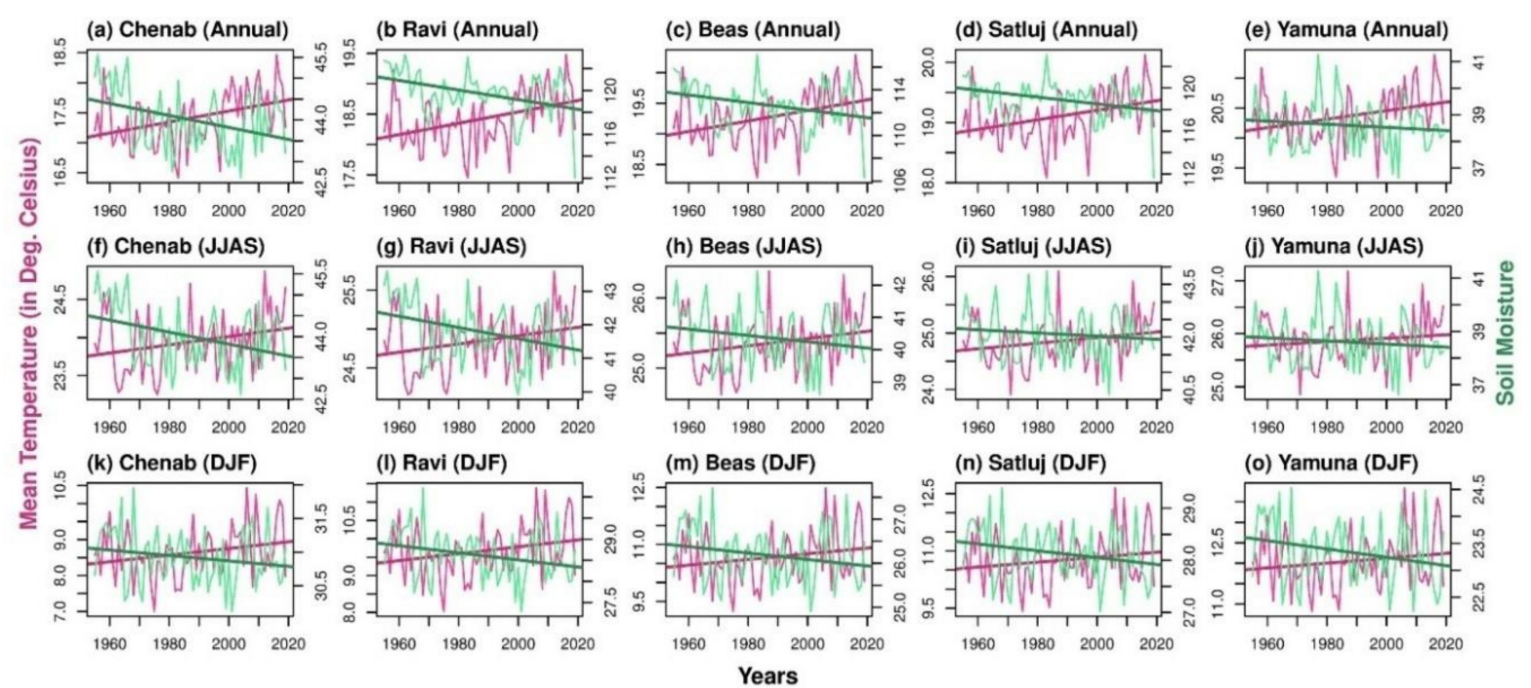

Figure 7. Basin-wise trend of mean temperature and soil moisture for annual, JJAS, and DJF seasons for the 1955-2019 period.

Rainfall and soil moisture trend for annual, JJAS, and DJF seasons are decreasing for all the basins across all the seasons (Figure 8a-o) except for the Chenab for the JJAS season (Figure 8f), which may be owing to difficult terrain and valley bottom topography with a high rate of melting of snow and glaciers with high elevations, rate of soil moisture absorptions not coping with melting of snow, and glaciers could be the reason that needs to be studied further. 
Table 2. Trend results for the Ravi, Beas, Satluj, Chenab, and Yamuna river basins. Results are based on the Mann-Kendall test (MKT) and Linear Regression Model (LRM). Values in italic represent $90 \%$ significance level, * represents 95\% significance level, and values in bold are significant at $99 \%$. All the results are for the period 1955-2019.

\begin{tabular}{|c|c|c|c|c|c|c|c|c|c|c|c|c|c|c|c|c|c|c|c|}
\hline \multirow{3}{*}{ River Basin } & \multirow{3}{*}{ Test } & \multicolumn{6}{|c|}{ Rainfall } & \multicolumn{6}{|c|}{ Temperature } & \multicolumn{6}{|c|}{ Soil Moisture } \\
\hline & & \multicolumn{2}{|c|}{ Annual } & \multicolumn{2}{|c|}{ JJAS } & \multicolumn{2}{|c|}{ DJF } & \multicolumn{2}{|c|}{ Annual } & \multicolumn{2}{|c|}{ JJAS } & \multicolumn{2}{|c|}{ DJF } & \multicolumn{2}{|c|}{ Annual } & \multicolumn{2}{|c|}{ JJAS } & \multicolumn{2}{|c|}{ DJF } \\
\hline & & z Stat & Slope & z Stat & Slope & z Stat & Slope & z Stat & Slope & z Stat & Slope & z Stat & Slope & z Stat & Slope & z Stat & Slope & z Stat & Slope \\
\hline \multirow{2}{*}{ Ravi } & MKT & -2.90 & -0.77 & -2.66 & -0.65 & -0.45 & -0.04 & 3.244 & 0.010 & $2.281 *$ & $0.006 *$ & 1.636 & 0.008 & -3.04 & -0.04 & -2.58 & -0.02 & -1.98 & -0.01 \\
\hline & LRM & & -0.90 & & -0.64 & & -0.05 & & 0.009 & & $0.005 *$ & & $0.009 *$ & & -0.04 & & -0.02 & & 0.003 \\
\hline \multirow{2}{*}{ Beas } & MKT & $-2.38 *$ & $-0.49 *$ & $-2.04 *$ & $-0.35^{*}$ & -0.25 & -0.02 & 3.27 & 0.01 & 1.93 & 0.006 & 1.31 & 0.01 & -2.62 & -0.04 & -1.53 & -0.01 & -1.47 & -0.01 \\
\hline & LRM & & -0.53 & & $-0.35 *$ & & -0.04 & & 0.01 & & 0.005 & & 0.01 & & -0.03 & & -0.01 & & 0.003 \\
\hline \multirow{2}{*}{ Satluj } & MKT & -1.32 & -0.19 & 0.69 & 0.06 & -1.24 & -0.19 & 2.90 & 0.01 & 1.90 & 0.005 & 0.96 & 0.005 & -2.79 & -0.03 & -0.71 & -0.004 & -1.58 & -0.01 \\
\hline & LRM & & $-0.26 *$ & & 0.04 & & -0.15 & & 0.01 & & 0.005 & & 0.01 & & -0.03 & & -0.005 & & 0.01 \\
\hline \multirow[b]{2}{*}{ Chenab } & MKT & 0.09 & 0.01 & 2.50 & 0.35 & -0.97 & -0.05 & 3.16 & 0.01 & 2.25 & 0.006 & 1.54 & 0.007 & -2.73 & -0.013 & -2.73 & -0.01 & -1.10 & -0.003 \\
\hline & LRM & & -0.10 & & $0.34 *$ & & -0.77 & & 0.01 & & 0.005 & & 0.009 & & -0.014 & & -0.01 & & 0.009 \\
\hline \multirow{2}{*}{ Yamuna } & MKT & -3.25 & -0.61 & $-1.97 *$ & -0.32 & -1.54 & -0.06 & 2.66 & 0.007 & 1.01 & 0.002 & 0.77 & 0.004 & -0.79 & -0.004 & -0.79 & -0.004 & -1.73 & -0.007 \\
\hline & LRM & & -0.56 & & $-0.28^{*}$ & & -0.11 & & 0.007 & & 0.003 & & 0.005 & & -0.005 & & -0.005 & & 0.001 \\
\hline
\end{tabular}




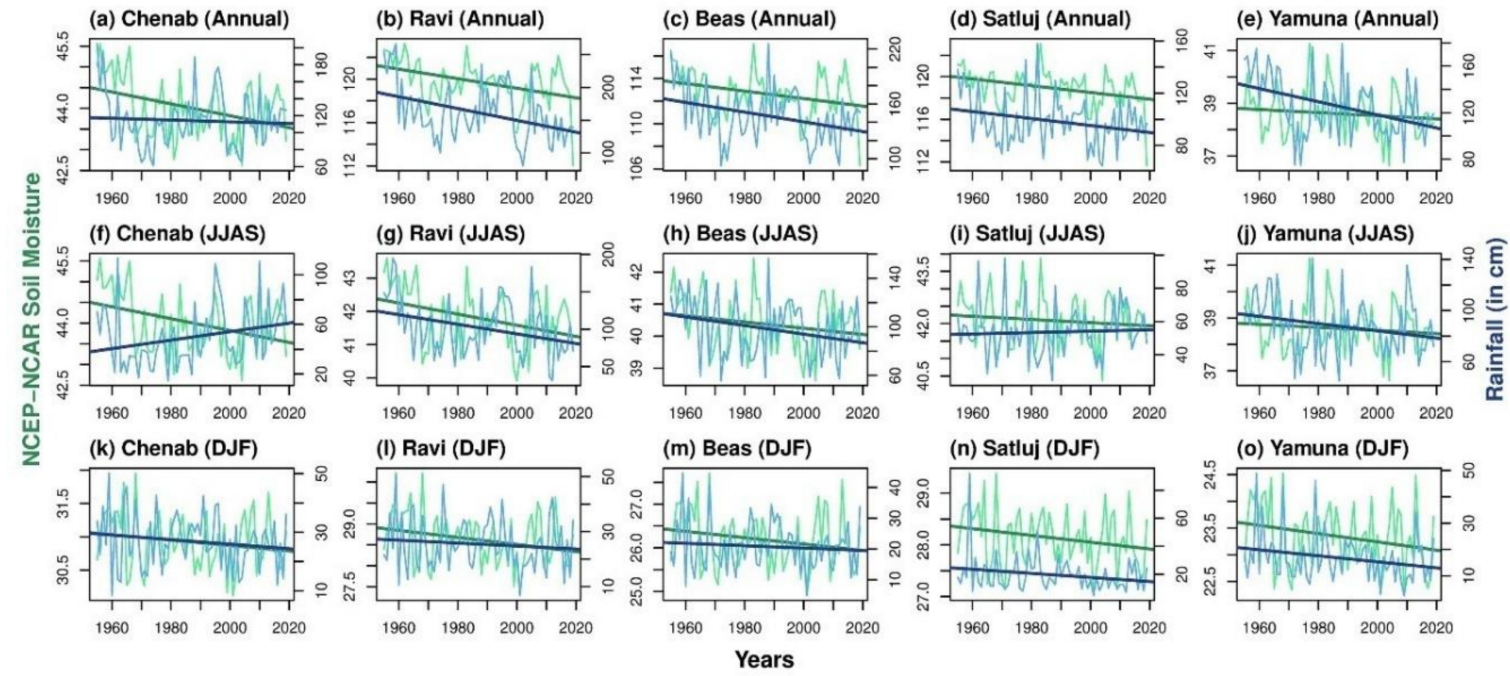

Figure 8. Basin-wise trend of mean rainfall and soil moisture for annual, JJAS, and DJF seasons for the 1955-2019 period.

The positive trend for all the period across all the basins indicates a homogenous increase in the temperature for the entire catchments. All the values are statistically significant at $90 \%, 95 \%$, and $99 \%$ in MKT and LRM trend analysis, as indicated in Table 2. For total annual rainfall except for the Chenab, all other basins have a negative trend and Chenab with a 0.09 MKT value showing a low positive trend (Figure 6a and Table 2). However, when the seasonal rainfall trend was analyzed for river basins, then it was found that, for the JJAS season, rainfall in both the Satluj and Chenab river basins shows an increasing trend (Figure 6f,i); for the other three basins (Ravi, Beas, and Yamuna), rainfall shows a decreasing trend (Figure $6 \mathrm{~g}, \mathrm{~h}, \mathrm{j}$ ). Coming to the DJF seasonal rainfall analysis, it was found that all river basins experience a decreasing trend of rainfall. The slope value of linear regression analysis suggests the steepness of the regression line. In other words, we can say, in what rate, a particular value is increasing or decreasing over time, that can be explained by the slope value of linear regression. In our case for annual rainfall and DJF seasonal rainfall, slope values of linear regression are negative for all river basins, but in the case of the JJAS rainfall analysis, the values are positive for Satluj and Chenab and negative for Ravi, Beas, and Yamuna (Table 2).

When temperature data for all river basins were analyzed, it was found that temperature has an increasing trend for all basins, as the "Z-stat" values are positive in each case for annual as well as seasonal temperatures (Figures 6 and 7 and Table 2). Similarly, the slope values in the LRM test are also positive for all basins, which once again proves that lines of temperature trend have been increasing for all basins.

In contrary to temperature, soil moisture analysis for all basins shows a decreasing trend for annual as well as seasonal moisture data. However, slope values in the LRM test show some variation, though the values are negative for annual and JJAS soil moisture, in the case of the DJF dataset, the results are positive (Table 2).

Basin-wise temperature, rainfall, and soil moisture patterns, as shown in Figures 3, 6 and 7, indicate the increase in temperature and decrease in rainfall and soil moisture in all the five river basins in the Himachal Pradesh. Increasing temperature trends may influence the melting of glaciers, which will lead to an increase in the runoff. However, a decrease in the DJF rainfall trend with declining winter snow depth [38-41] across all the basins will lead to less flow in the stream and how all the runoff-river hydropower will work in the future is a matter of concern in particular and for Himalayan biodiversity in general. With the impact of climate change, how the cumulative responses from the Himalayas ecology will reflect society through the dry streams of several river regimes and its sub-regimes owing to runoff-river systems is moving towards the worst phases of hydropower and 
water-related problems in the Himachal Pradesh in the near future; these are our observations from the primary survey.

\subsection{Socioecological Survey}

Out of the five river basins we have surveyed in three basins, i.e., the Ravi, the Beas, and the Satluj basins, we found almost similar perceptions and observations by village peoples related to hydropower projects. Out of the 12 villages we visited, 4 from each basin, the Ravi, the Beas, and the Satluj basins, and covered 120 local peoples, all have serious negative ecological observations owing to HPP. The crisis of drinking water, the disappearance of springs, deforestation, problems in terrace farming, increases of landslides and dearth of aquatic lives are some very serious ecological and loss of biodiversity problems faced within the Himachal Himalayas. During our survey, we came to know that only $15 \%$ of water is flowing in the natural stream across all the seasons in Himachal Pradesh based on the amount of water availability. With decreasing rainfall and soil moisture, and increasing temperature across all the five river basins, dry streams is a major reason for the disappearance of springs observed by local people; if this issue is not addressed in time, then it must have serious ecological implications in Himachal Pradesh. Though spring disappearance is not directly linked to climate change, overexploitations of HPP is one of the major factors for it.

\subsubsection{Spring Disappearance}

In high elevation mountains, groundwater discharges occur through springs. Springs in the Himalayas range of Himachal Pradesh are perennial in nature. Tap water or piped water is not available to the sparsely populated areas, located on the top of the mountains. People in the remote hill areas use water from the spring for their drinking, domestic as well as irrigation for their terrace farming, horticulture, and other staple crops predominantly in the districts of Kinnaur, Lahul, and Spiti, Kullu, Chamba, and Mandi of Himachal Pradesh. The economy and livelihood of these areas depend upon the springs (Figure 9). Spring water helps to maintain the soil moisture in the hilly terrain. There are numerous reports based on local Non-Government Organisations (NGO) [42], community-based studies, state and central government agencies [43] that focused on the water crisis in the Himalayan riparian states due to the disappearance of natural springs. The NitiAyog, a think-tank of the central government of India, has recently carried out a study to understand the spring disappearance and possibility of springs rejuvenations in the Himalayan belt [43]. The study highlighted that about 50\% of the springs in the Himalayan belts are already dried up due to anthropogenic factors and hydropower projects. The main causes of spring disappearance are diversion of stream water through long concrete tunnels for hydropower purposes and many river streams have cascading HPP pipelined one by one that further blocks the aquifers zones of the soil. More than $90 \%$ of respondents have expressed that the disappearance of springs is creating serious livelihood problems across all the basins.

\subsubsection{Risk of Disasters}

There are frequent occurrences of natural hazards in the state of Himachal Pradesh. The hills and mountains of the state are liable to suffer landslides during monsoons and also in high-intensity earthquakes. In case of earthquake vulnerability, the districts Kangra, Hamirpur, and Mandi fall in a very high vulnerable category. The districts that fall in the landslide vulnerability category areChamba, Kullu, and Kinnaur. The avalanche hazard vulnerability map suggests that the districts of Lahaul-Spiti and Kinnaur are very highly vulnerable. The HPPs in the Himachal Pradesh are installed in more than $5500 \mathrm{~m}$ elevation on the Sutlej in Kinnaur to less than $450 \mathrm{~m}$ elevation on the Yamuna sub-basin in Sirmour districts (Figure 1). More than half of the HPPs are within 2000-4000 m elevation, which is very vulnerable to landslides, earthquakes [44], and flash floods. The entire Himachal Pradesh is situated in the type- $\mathrm{V}$ zone, the highest vulnerable seismic zone as per the National Disaster Management Authority of India (NDMA) (Figure 10). 


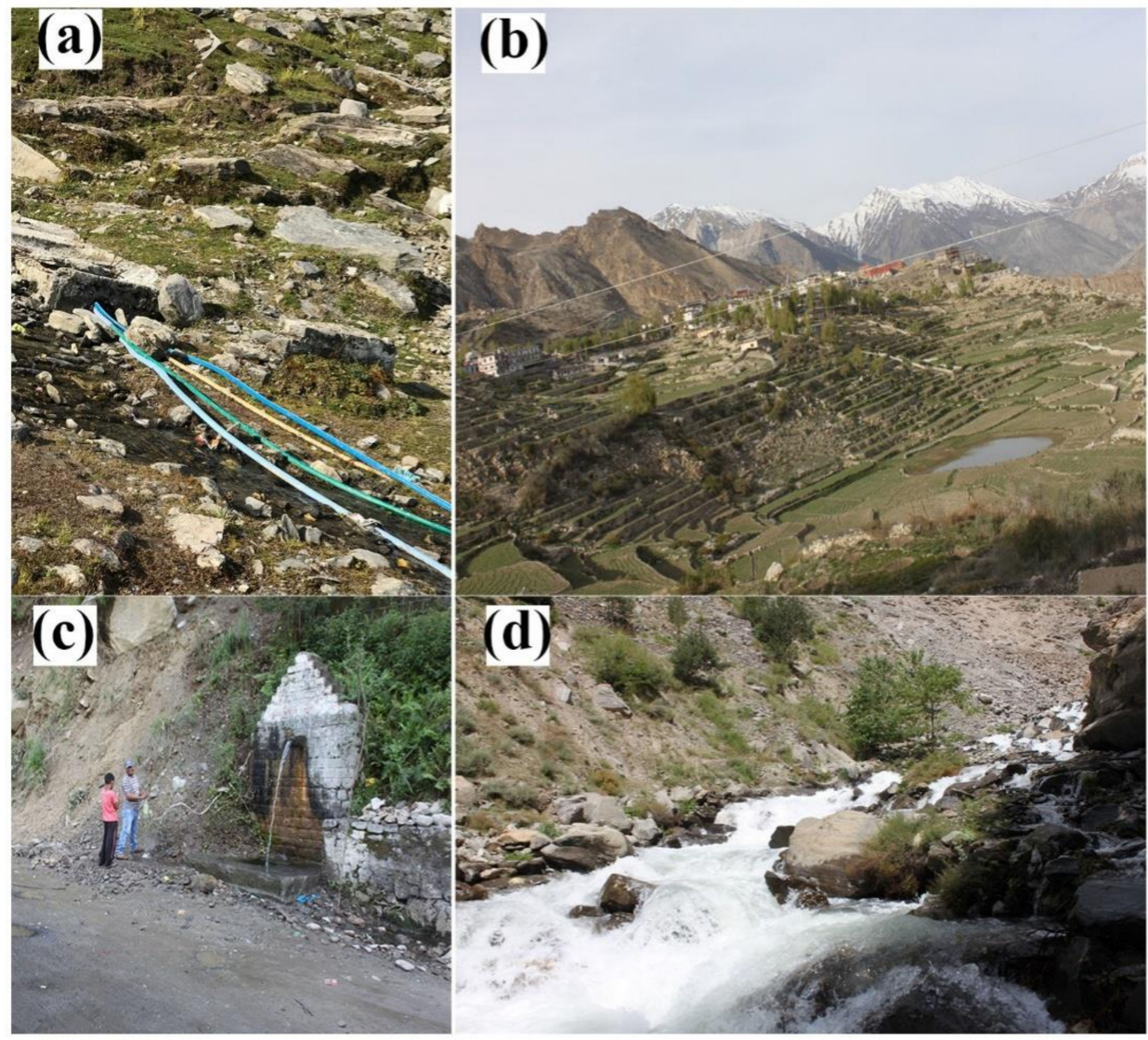

Figure 9. Photographs tell the importance of springs in the daily lives of people living in higher altitudes within Himachal Pradesh in the Indian Himalayas: (a) near Rohtang Pass of Kullu districts at $3100 \mathrm{~m}$ elevations of Beas basin, water from spring used for household purpose; (b) Nako village of Kinnaur districts of Satluj basin at 3200 m elevations, harvested water from spring for horticulture; (c) on the way to Bharmour, Chamba at 1500 m elevation, spring water has been used by tourist and local people of the Ravi basin; (d) natural spring within the Satluj basin of Kinnaur districts. All photographs were taken during our primary survey.

Among various types of HPPs in the Himachal Pradesh, 85\% are runoff-river-based power plants that operate through the diversion of stream water by the concrete tunnel. Making tunnels within the Himalayan rock structures throughout Himachal Pradesh where tunnels are varying from a few hundred meters to more than $10 \mathrm{~km}$ creates hallowing in the mountain. Use of explosives for blasting in the bulk emulsion, big hole drilling through vibrations and compressors, the risk of damage to the underground water cycle, deforestation, fragmentations of rocks and slope failures trigger the avalanches (Figure 10a), landslides (Figure 10b), and earthquakes (Figure 10c) that increase the hydrogeological disasters in the region [42,45]. "Landslides are very frequent nowadays owing to massive constructional activities are going on in recent years than one-two decades before solely because of HPP," told by $85 \%$ of anonymous respondents who prefer not to be named. During our survey, we came across very serious landslides near the Kotpuri of Mandi districts, in which 46 people were killed in August 2017; one landslide occurred near Bharmour, though no life loss took place, but the road was blocked for one week in October 2019. Reports of landslides from our primary survey (Figures 10b and 11) explain how all of Himachal Pradesh is vulnerable to landslides. 

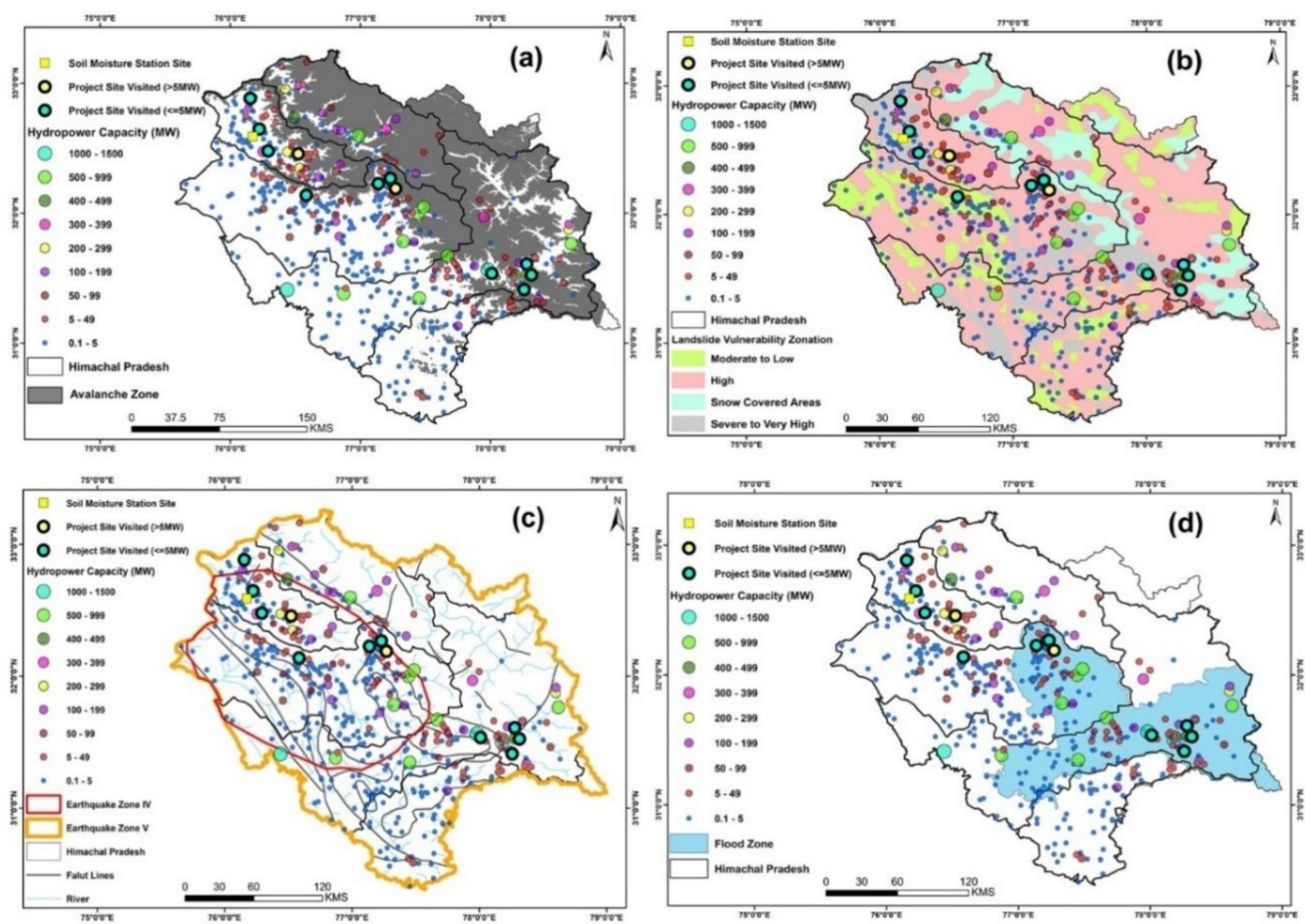

Figure 10. Spatial hazard zonation map for Himachal Pradesh covering all the basins, consisting of (a) avalanche, (b) landslide, (c) earthquake, (d) flood vulnerability, as per the National Disaster Management Authority, Ministry of Home Affairs, Government of India.

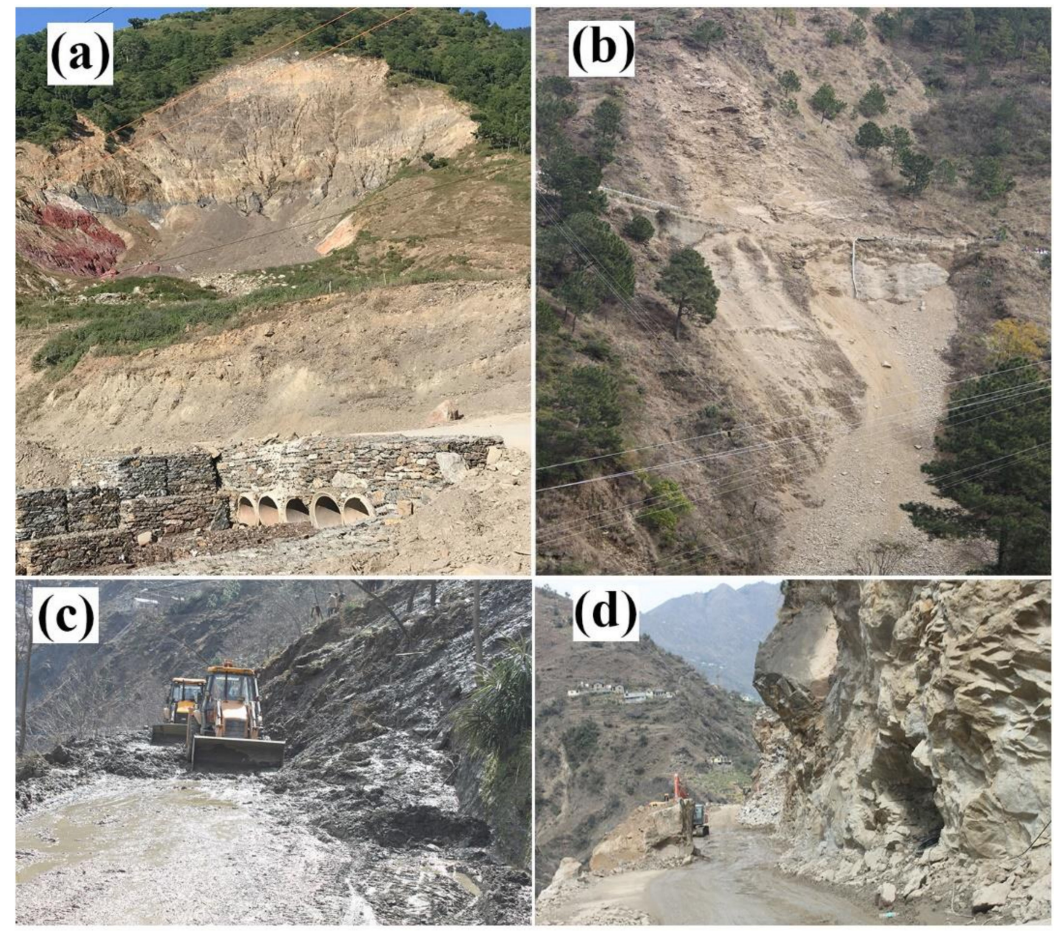

Figure 11. Landslides: (a) Kotpuri of Mandi districts, a massive landslide occurred on 13 August 2017, 46 people died, that we visited during the primary survey; (b) huge landslide blocked the road for 2 days in Chamba districts; (c) on our way to Bharmour in October 2019, a landslide blocked the road for one week; (d) landslide near Bhaba Nagar of the Kinnaur districts within the Satluj basin. All the photographs were taken during our primary survey. 


\section{Discussion}

The possible impact of dams on the river flow regimes across the world varies based on the terrain, topography, ecology, and socioeconomic conditions of the region. In the climate change scenarios and impact of global warming, estimated runoff contributions to the total runoff from snow and glacier melt in the Beas at 35\%, the Chenab 49\%, and the Satluj 60\% at present are going to increase with the increase in snow and glaciers melting [46-48]. Ali et al. [8] suggested the wetter $17.04 \pm 20.76 \%$ and $15.30 \pm 20.16 \%$ increase in the annual mean precipitation in the Nathpa Jhakri (1500 MW) and Bhakra Nangal (1300 MW) big storage dams of the Satluj basin, respectively, in the near future was owing to snow and glaciers melting. The big dam's socio-environmental impacts are many [49-53]; small dams are not fully safe in biodiversity conservations either. The Himalayan ranges of the Himachal Pradesh are facing serious ecological threats from the runoff-river tunnel-based small dams as well. Less than $5 \mathrm{MW}$ capacity runoff-river dams considered as "green and clean" dams are no more "green and clean" from risk and tensions [54,55]. Long term means that temperature and rainfall MKT and LRM analysis [56,57] shows an increase and decreasing trend, respectively, in Himachal Pradesh [35]. Various previous studies show declining snow cover and depth in the western Himalayas regions, including Himachal Pradesh. Huber et al. [58-60], in their study, found that seasonal snow cover depth and duration have been declining in the last 2-3 decades in the western Himalayas. The India National Satellite (INSAT) derived snow cover data and National Centers for Environmental Prediction/National Center for Atmospheric Research (NCEP/NCAR) climate data analysis show snow depth weakening in the western Himalayas [38]. The increasing minimum temperature is the dominant factor for decreasing winter snowfall trends in the Satluj basin [61,62]. People's perceptions and observations also confirm the declining depth of snowfall in the higher altitudes of Himachal Pradesh [35]. Increasing temperature trend across all seasons within all the five river basins (Figure 6) may lead to increase the runoff in those river basins like Beas, Chenab, and Satluj, and this will be a dividend for the hydropower plants located within these basins, but with decreasing rainfall (Figure 7), and snow depth will create difficult situations for hydropower managers to maintain the plants. Decreasing soil moisture trend within all the river basins across all the seasons, as shown in Table 2 and Figures 5, 8, S5 and S6, will not only impact the hydropower [63-69], but also influence the horticulture, terrace farming, aquatic life, and Himalayan biota [70] that already threatened with increasing frequency of landslides, earthquakes [44], and other disasters within Himachal Pradesh. Shrestha et al. [71] investigated the widespread climate change impact on the Himalayan ecosystem and concluded that rate of warming is higher than the global average and will make the Himalayas more vulnerable to climate change. Several other studies also have similar findings on the impact of climate change on horticulture and water resources ecosystem in the Himalayas [72,73].

\section{Conclusions}

With the climate change scenarios, the long-term impacts of HPPs on the Himachal Himalayas are a serious threat to the river hydrology and biodiversity of the region. With an increasing number of landslides, avalanches, and flash floods, the crisis of spring disappearance in the Himachal Pradesh should be critically analyzed to provide scientific long-term solutions and mitigation from hydrogeological disasters. Runoff-river small dam boom in the region has been overestimated in terms of economic benefits and underestimated in terms of the effects on the diverse biota. The non-accountable approach of local governments to the small hydropower owners in the name of green and clean energy often raises the questions on the transparency processed followed during the approval of the dam and if the people affected at the local level are well informed about risks and consequences. Our basin-wise spatial distributions, linear associations and MKT and LRM trend analysis of rainfall, soil moisture, and temperature have shown the potential impact of hydrological implications within Himachal Pradesh. Ripple effects of runoff-river HPP to the ecosystem services and biodiversity in the Himachal Pradesh are hardly taken into account for the long-term assessment, especially for the horticulture and aquatic livelihoods. The absence of dam reservoirs observations' long-term records and streamflow 
data are the major limitations of this work. Future research on HPP boom within the Himalayan biodiversity will depend on how the climate change effects will impacts the river flow regimes.

Supplementary Materials: The following are available online at http://www.mdpi.com/2073-4441/12/10/2739/s1, Figure S1: Pentads showing total rainfall in winter season (DJF) in Himachal Pradesh. Each pentad shows the mean of the five years from 1955-2019., Figure S2. Pentads showing total rainfall in monsoon season (JJAS) in Himachal Pradesh. Each pentad shows the mean of the five years from 1955-2019. Figure S3. Pentads showing mean temperature in winter season (DJF) in Himachal Pradesh. Each pentad shows the mean of the five years from 1955-2019. Figure S4. Pentads showing mean temperature in monsoon season (JJAS) in Himachal Pradesh. Each pentad shows the mean of the five years from 1955-2019. Figure S5. Pentads showing total soil moisture in winter season (DJF) in Himachal Pradesh. Each pentad shows the mean of the five years from 1955-2019. Figure S6. Pentads showing total soil moisture in monsoon season (JJAS) in Himachal Pradesh. Each pentad shows the mean of the five years from 1955-2019.

Author Contributions: N.S. conceptualized the central idea, carried out the analysis, drew all the figures and wrote the paper. T.S. supervised the work, A.S. and A.P. helped to acquire the data and formal analysis. K.T. commented on the manuscript. All authors have read and agreed to the published version of the manuscript.

Funding: This work has been supported by JSPS Kakenhi Grant-in-Aid id:18F18360.

Acknowledgments: The India Meteorological Department, Pune provided the gridded spatial data for Rainfall and temperature. The IRI/LDEO Climate Data Library provided online access to NCEP-NCAR soil moisture reanalyzed data for 10-200 cm depth. We are highly thankful to Mohinder Kumar Slaria, Government Post Graduate College, Chamba, Himachal Pradesh, who facilitated the local guidance and assistance for the field survey and data collection in different locations of Himachal Pradesh. NCAR Command Language was used to draw the spatial distribution maps in the present study.

Conflicts of Interest: The authors declare that they have no competing interests.

\section{References}

1. Rampini, C. Impacts of Hydropower Development along the Brahmaputra River in Northeast India on the Resilience of Downstream Communities to Climate Change Impacts. Ph.D. Thesis, University of California, Santa Cruz, CA, USA, 2016.

2. Kumar, D.; Katoch, S.S. Dams turning devils: An insight into the public safety aspects in operational run of the river hydropower projects in western Himalayas. Renew. Sustain. Energy Rev. 2017, 67, 173-183. [CrossRef]

3. Grumbine, R.E.; Pandit, M.K. Threats from India's Himalaya dams. Science 2013, 339, 36-37. [CrossRef]

4. Zarfl, C.; Lumsdon, A.E.; Berlekamp, J.; Tydecks, L.; Tockner, K. A global boom in hydropower dam construction. Aquat. Sci. 2015, 77, 161-170. [CrossRef]

5. Kelly-Richards, S.; Silber-Coats, N.; Crootof, A.; Tecklin, D.; Bauer, C. Governing the transition to renewable energy: A review of impacts and policy issues in the small hydropower boom. Energy Policy 2017, 101, 101,251-264. [CrossRef]

6. Winemiller, K.O.; McIntyre, P.B.; Castello, L.; Fluet-Chouinard, E.; Giarrizzo, T.; Nam, S.; Baird, I.G.; Darwall, W.; Lujan, N.K.; Harrison, I.; et al. Balancing hydropower and biodiversity in the Amazon, Congo and Mekong. Science 2016, 351, 128-129. [CrossRef] [PubMed]

7. Lees, A.C.; Peres, C.A.; Fearnside, P.M.; Schneider, M.C.; Zuanon, J.A.S. Hydropower and the future of Amazonian biodiversity. Biodivers. Conserv. 2016, 25, 451-466. [CrossRef]

8. Ali, S.A.; Aadhar, S.; Shah, H.L.; Mishra, V. Projected increase in hydropower production in India under climate change. Sci. Rep. 2018, 8, 12450. [CrossRef]

9. Nilsson, C.; Reidy, C.A.; Dynesius, M.; Revenga, C. Fragmentation and Flow Regulation of the World's Large River System. Science 2005, 308, 405-408. [CrossRef]

10. IHA-International Hydropower Association. Activity Report; International Hydropower Association: London, UK, 2019.

11. Pai, D.S.; Sridhar, L.; Rajeevan, M.; Sreejith, O.P.; Satbhai, N.S.; Mukhopadhyay, B. Analysis of the daily rainfall events over India using a new long period $(1901-2010)$ high resolution $(0.25 \times 0.25)$ gridded rainfall data set. Clim. Dyn. 2014, 65, 1-18.

12. Srivastava, A.K.; Rajeevan, M.; Kshirsagar, S.R. Development of a high resolution daily gridded temperature data set (1969-2005) for the Indian region. Atmos. Sci. Lett. 2009, 10. [CrossRef] 
13. Kalnay, E.M.; Kanamitsu, R.; Kistler, W.; Collins, D.; Deaven, L.; Gandin, M.; Iredell, S.; Saha, G.; White, J.; Woollen, Y.; et al. The NCEP/NCAR 40-Year Reanalysis Project. Bull. Am. Meteorol. Soc. 1996, 77, 437-471. [CrossRef]

14. Mann, H.B. Non-parametric tests against trend. Econometrica 1945, 13, 163-171. [CrossRef]

15. Sen, P.K. Estimates of the regression coefficient based on Kendall's tau. J. Am. Stat. Assoc. 1968, 63, 1379-1389. [CrossRef]

16. Gaudard, L.; Gilli, M.; Romerio, F. Climate Change Impacts on Hydropower Management. Water Resour. Manag. 2013, 27, 5143-5156. [CrossRef]

17. Gaudard, L.; Romerio, F.; Dalla Valle, F.; Gorret, R.; Maran, S.; Ravazzani, G.; Stoffel, M.; Volonterio, M. Climate change impacts on hydropower in the Swiss and Italian Alps. Sci. Total Environ. 2014, 493, 1211-1221. [CrossRef]

18. Gaudard, L.; Avanzi, F.; De Michele, C. Seasonal aspects of the energy-water nexus: The case of a run-of-the-river hydropower plant. Appl. Energy 2018, 210, 604-612. [CrossRef]

19. Pearce, F. The Dammed: Rivers, Dams, and the Coming World Water Crisis; Bodley Head: London, UK, 1992.

20. Intergovernmental Panel on Climate Change. Intergovernmental Panel on Climate Change Fourth Assessment Report by Working Group III, Mitigation of Climate Change: Greenhouse Gas Emission Trends; IPCC: Geneva, Switzerland, 2007.

21. IPCC-Inter-governmental Panel on Climate Change. Special Report on Renewable Energy Sources and Climate Change Mitigation; Special Report of IPCC; Cambridge University Printing Press: Cambridge, UK, 2012; Chapter 5: Hydropower.

22. Golombek, R.; Kittelsen, S.A.C.; Haddeland, I. Climate change: Impacts on electricity markets inWestern Europe. Clim. Chang. 2012, 113, 357-370. [CrossRef]

23. Sahu, N.; Yamashiki, Y.; Behera, S.; Takara, K.; Yamagata, T. Large impacts of Indo-Pacific climate modes on the extreme streamflows of Citarum River in Indonesia. J. Glob. Environ. Eng. 2012, 17, 1-8.

24. Sahu, N.; Robertson, A.W.; Boer, R.; Behera, S.; DeWitt, D.G.; Takara, K.; Kumar, M.; Singh, R.B. Probablistic seasonal streamflow forecasts of the Citarum River, Indonesia, based on general circulation models.Stoch.Environ. Res. Risk Assess. 2017, 31, 1747-1758. [CrossRef]

25. Sahu, N.; Singh, R.B.; Kumar, P.; Silva, R.V.D.; Behera, S.K. La Niña impacts on Austral Summer extremely high-streamflow events of the Paranaíba River in Brazil. Adv. Meteorol. 2013, 2013, 461693. [CrossRef]

26. Archer, D.R.; Fowler, H.J. Spatial and temporal variations in precipitation in the Upper Indus Basin: Global teleconnections and hydrological implications. Hydrol. Earth Syst. Sci. 2004, 8, 47-61. [CrossRef]

27. Singh, D.; Juyal, V.; Sharma, V. Consistent seasonal snow cover depth and duration variability over the Western Himalayas (WH). J. Earth Syst. Sci. 2016, 125, 1451-1461. [CrossRef]

28. Singh, P.; Kumar, N. Effect of Orography on precipitation in the western Himalayan region. J. Hydrol. 1997, 199, 183-206. [CrossRef]

29. Mir, R.A.; Jain, S.K.; Saraf, A.K.; Goswami, A. Decline in Snowfall in Response to Temperature in Satluj Basin, Western Himalaya. J. Earth Syst. Sci. 2015, 124, 365-382. [CrossRef]

30. Majone, B.; Villa, F.; Deidda, R.; Bellin, A. Impact of climate change and water use policies on hydropower potential in the south-eastern Alpine region. Sci. Total. Environ. 2016, 543, 965-980. [CrossRef]

31. Agrawala, S.; Raksakulthai, V.; Aalst, M.; Larsen, P.; Smith, J.; Reynolds, J. Development and Climate Change in Nepal: Focus on Water Resources and Hydropower; Organization for Economic Cooperation and Development: Paris, France, 2003.

32. Ahlers, R.; Budds, J.; Joshi, D.; Merme, V.; Zwarteveen, M. Framing hydropower as green energy: Assessing drivers, risks and tensions in the Eastern Himalayas. Earth Syst. Dyn. 2015, 6, 195-204. [CrossRef]

33. Jaiswal, A.K.; Bhan, S.C.; Karandikar, A.S.; Gujar, M.K. Seasonal and annual rainfall trends in Himachal Pradesh during 1951-2005. Mausam 2015, 66, 247-264.

34. Guhathakurta, P.; Rajeevan, M. Trends in the Rainfall Pattern over India. Int. J. Climatol. 2008, 28, 1453-1469. [CrossRef]

35. Sahu, N.; Saini, A.; Behera, S.K.; Sayama, T.; Sahu, L.; Van- Thanh- Van, N.; Takara, K. Why Apple Orchards are shifting to the Higher Altitudes of the Himalayas? PLOS ONE 2020, 15, e0235041. [CrossRef]

36. Prasad, R.; Rana, S.S. Length of rainy season and climatic water balance as influenced by climate change in the sub temperate and sub tropical mid hills of Himachal Pradesh. J. Agric. Phys. 2010, 10, 44-49. 
37. Bhan, S.C.; Singh, M. Analysis of total precipitation and snowfall pattern over Shimla. J. Agrometeorol. 2011, 13, 141-144.

38. Kripalani, R.H.; Kulkarni, A.; Sabade, S.S. Western Himalayan Snow Cover and Indian Monsoon Rainfall: A re-examination with INSAT and NCEP/NCAR Data. Theor. Appl. Climatol. 2003, 74, 1-18. [CrossRef]

39. Boelens, R.; Shah, E.; Bruins, B. Contested Knowledges: Large Dams and Mega-Hydraulic Development. Water 2019, 11, 416. [CrossRef]

40. Lutz, A.F.; Immerzeel, W.W.; Shrestha, A.B.; Bierkens, M.F.P. Consistent increase in high Asia's runoff due to increasing glacier melt and precipitation. Nat. Clim. Chang. 2014, 4, 587. [CrossRef]

41. Madani, K.; Lund, J.R. Estimated impacts of climate warming on California's high-elevation hydropower. Clim. Chang. 2010, 102, 521-538. [CrossRef]

42. Huber, A. Hydropower in the Himalayan Hazardscape: Strategic Ignorance and the Production of Unequal Risk. Water 2019, 11, 414. [CrossRef]

43. Niti Aayog, Government of India. Report on Disappearance of Spring in Himachal Pradesh; NITI Aayog: New Delhi, India, 2018.

44. Schwanghart, W.; Ryan, M.; Korup, O. Topographic and seismic constraints on the vulnerability of Himalayan hydropower. Geophys. Res. Lett. 2018, 45, 8985-8992. [CrossRef]

45. Yan, Y.; Zhang, Y.; Huang, C. Impact of blasting vibration on soil slope stability. Electron. J. Geotech. Eng. 2014, 19, 6559-6568.

46. Alfieri, L.; Perona, P.; Burlando, P. Optimal water allocation for an alpine hydropower system under changing scenarios. Water Resour. Manag. 2006, 20, 761-778. [CrossRef]

47. Avtar, R.; Sahu, N.; Aggarwal, A.K.; Chakraborty, S.; Kharrazi, A.; Yunus, A.P.; Dou, J.; Kurniawan, T.A. Exploring Renewable Energy Resources Using Remote Sensing and GIS-A Review. Resources 2019, 8, 149. [CrossRef]

48. Xu, Z.; Cheng, L.; Luo, P.; Liu, P.; Zhang, L.; Li, F.; Liu, L.; Wang, J. A Climatic Perspective on the Impacts of Global Warming on Water Cycle of Cold Mountainous Catchments in the Tibetan Plateau: A Case Study in YarlungZangbo River Basin. Water 2020, 12, 2338. [CrossRef]

49. Dobreva, I.D.; Bishop, M.P.; Bush, A.B.G. Climate-Glacier Dynamics and Topographic Forcing in the Karakoram Himalaya: Concepts, Issues and Research Directions. Water 2017, 9, 405. [CrossRef]

50. Mehta, V.K.; Rheinheimer, D.E.; Yates, D.; Purkey, D.R.; Viers, J.H.; Young, C.A.; Mount, J.F. Potential impacts on hydrology and hydropower production under climate warming of the Sierra Nevada. J. Water Clim. Chang. 2011, 2, 29-43. [CrossRef]

51. McCully, P. Silenced Rivers: The Ecology and Politics of Large Dams; Zed Books: London, UK, 2001.

52. Cernea, M. Hydropower Dams and Social Impacts: A Sociological Perspective; World Bank Group: Washington, DC, USA, 1997.

53. Cherry, J.E.; Knapp, C.; Trainor, S.; Ray, A.J.; Tedesche, M.; Walker, S. Planning for climate change impacts on hydropower in the Far North. Hydrol. Earth Syst. Sci. 2017, 21, 133-151. [CrossRef]

54. Chilkoti, V.; Bolisetti, T.; Balachandar, R. Climate change impact assessment on hydropower generation using multi-model climate ensemble. Renew. Energy 2017, 109, 510-517. [CrossRef]

55. Hamlet, A.F.; Lettenmaier, D.P. Effects of climate change on hydrology and water resources in the Columbia River Basin. J. Am. Water Resour. Assoc. 1999, 35, 1597-1623. [CrossRef]

56. Panda, A.; Sahu, N. Trend analysis of seasonal rainfall and temperature pattern in Kalahandi, Bolangir and Koraput districts of Odisha, India. Atmos. Sci. Lett. 2019, 20, e932. [CrossRef]

57. Duan, W.; He, B.; Sahu, N.; Luo, P.; Nover, D.; Hu, M.; Takara, K. Spatiotemporal variability of Hokkaido's seasonal precipitation in recent decades and connection to water vapour flux. Int. J. Climatol. 2017, 37, 3660-3673. [CrossRef]

58. Hamududu, B.; Killingtveit, A. Assessing climate change impacts on global hydropower. Energies 2012, 5, 305-322. [CrossRef]

59. Huber, A.; Gorostiza, S.; Kotsila, P.; Beltrán, M.J.; Armiero, M. Beyond "socially constructed" disasters: Re-politicizing the debate on large dams through a political ecology of risk. Capital. Nat. Soc. 2017, 28, 48-68. [CrossRef]

60. Vicuna, S.; Dracup, J.A.; Dale, L. Climate change impacts on two high-elevation hydropower systems in California. Clim. Chang. 2011, 109, 151-169. [CrossRef] 
61. Wagner, T.; Themeß1, M.; Schüppel, A.; Gobiet, A.; Stigler, H.; Birk, S. Impacts of climate change on stream flow and hydro power generation in the Alpine region. Environ. Earth Sci. 2016, 76. [CrossRef]

62. Molarius, R.; Keranen, J.; Schabel, J.; Wessberg, N. Creating a climate change risk assessment procedure: Hydropower plant case, Finland. Hydrol. Res. 2010, 41, 282-294. [CrossRef]

63. Mukheibir, P. Potential consequences of projected climate change impacts on hydroelectricity generation. Clim. Chang. 2013, 121, 67-78. [CrossRef]

64. Markoff, M.S.; Cullen, A.C. Impact of climate change on Pacific Northwest hydropower. Clim. Chang. 2008, 87, 451-469. [CrossRef]

65. Schaefli, B.; Hingray, B.; Musy, A. Climate change and hydropower production in the Swiss Alps: Quantification of potential impacts and related modelling uncertainties. Hydrol. Earth Syst. Sci. 2007, 11, 1191-1205. [CrossRef]

66. Nepal, S. Impacts of climate change on the hydrological regime of the Koshi river basin in the Himalayan region. J. Hydro Environ. Res. 2016, 10, 76-89. [CrossRef]

67. Savelsberg, J.; Schillinger, M.; Schlecht, I.; Weigt, H. The Impact of Climate Change on Swiss Hydropower. Sustainability 2018, 10, 2541. [CrossRef]

68. Solaun, K.; Cerdá, E. The impact of climate change on the generation of hydroelectric power-a case study in southern Spain. Energie 2017, 10, 1343. [CrossRef]

69. Schwanghart, W.; Worni, R.; Huggel, C.; Stoffel, M.; Korup, O. Uncertainty in the Himalayan energy-water nexus: Estimating regional exposure to glacial lake outburst floods. Environ. Res. Lett. 2016, 11, 074005. [CrossRef]

70. Shrestha, U.B.; Gautam, S.; Bawa, K.S. Widespread climate change in the Himalayas and associated changes in local ecosystems. PLoS ONE 2012, 7. [CrossRef] [PubMed]

71. Chaudhary, P.; Bawa, K.S. Local perceptions of climate change validated by scientific evidence in the Himalayas. Biol. Lett. 2011, 7, 767-770. [CrossRef] [PubMed]

72. Momblanch, A.; Beevers, L.; Srinivasalu, P.; Kulkarni, A.; Holman, I.P. Enhancing production and flow of freshwater ecosystem services in a managed Himalayan river system under uncertain future climate. Clim. Chang. 2020, 1-19. [CrossRef]

73. Singh, J.; Sahany, S.; Robock, A. Can stratospheric geoengineering alleviate global warming-induced changes in deciduous fruit cultivation? The case of Himachal Pradesh (India). Clim. Chang. 2020, 1-21. [CrossRef] 